\title{
GSTM3 Gene
}

National Cancer Institute

\section{Source}

National Cancer Institute. GSTM3 Gene. NCI Thesaurus. Code C112072.

This gene is involved in both glutathione metabolism and cellular detoxification. 